\title{
Restoring the 'Mam': Archives, Access and Research into Women's Pasts in Wales
}

\author{
MANDI O'NEILL
}

The history of Welsh people has often been camouflaged in British history yet women have been rendered inconspicuous within their own Welsh history. ${ }^{1}$

\footnotetext{
$\mathrm{I}$

t has been suggested that 'Welsh women are culturally invisible' ${ }^{2}$ in a country which has had a predominantly male workforce in its modern history which resulted in a strong cultural identity around rugby and male voice choirs which excluded women. ${ }^{3}$ Welsh women were strongly identified with the domestic sphere and have been represented as a sort of nostalgic, idealised mother: the 'mam', the matriarch of the home, waging a constant battle, often in the face of economic deprivation, to keep her home and family clean and well-fed, often at the expense of her own health. 'Cleanliness is next to godliness',
} 
could have been her mantra: her reputation - which was all-important was one of hard work, thrift and piety. Rarely, if ever, working outside the home, social activities revolved around the chapel. Pubs and politics were for the men. ${ }^{4}$ Government statistics have tended to reinforce the somewhat homogenous, domestic view of Welsh women. In the mid interwar period, only twenty-one percent of women in Wales were recorded as economically active $\mathrm{e}^{5}$ although oral history interviews reveal that women did take on additional work, often in the home, to supplement family income. ${ }^{6}$

While the idealised 'mam' is rooted firmly in the coalmining communities of the South Wales Valleys, there were plenty of women in urban areas such as Cardiff and Swansea and large parts of rural Wales who did not conform to this image. So on the one hand a significant proportion of women - the 'mams' - are represented in the traditional histories of Wales albeit fleetingly and inaccurately, whilst another equally significant group of 'other' women are completely unrepresented in these histories. ${ }^{7}$ These 'other' women include, for example, 'thousands of women' who were employed on Cardiff Docks ${ }^{8}$ as well as women who worked at the Freeman's cigar factory in Grangetown, a noted local employer of women in the city, whom we know little about. ${ }^{9}$

Inevitably, then, much of the research carried out by Welsh feminist historians has centred on women's experiences in the home - the 'private sphere'. This is perhaps due to the dominant hold the representation of the 'mam' has had on the perceived identity of women in Wales and it has taken a concerted effort to shift her from her pedestal. ${ }^{10}$ In Wales, as elsewhere, feminist historians have long recognised the need for finding alternative ways to discover more about women's pasts: diaries, autobiographies, letters, pamphlets, photographs and, particularly, oral history. This material has helped counter traditional stereotypes of Welsh women ${ }^{11}$ but there are still a number of areas of potential research that will offer a more diverse picture of women's lives. ${ }^{12}$ Access to existing material is vital and it is also important to raise awareness of the importance of women's history and the need to preserve material relevant to women's lives for future researchers of all kinds.

This article touches on these issues and looks at two Welsh archives, both of which are concerned with those people whose 'lives were conducted off-centre-stage in the margins' and who were not considered important enough to be included in traditional histories. ${ }^{13}$ It is based on the dissertation I completed for an MA in Women's Studies in 2009. The initial idea for the dissertation had been to find out more about the lives of white Welsh women in Butetown, Cardiff, who married African, 
Arabic, Asian and West Indian seamen during the early part of the twentieth century. My intention was to try to 'find' and interview some of these women - or, more likely, their children - in order to find out how they had sustained their families and their community in the face of racist employment policies, negative stereotyping and general hostility to their community by outsiders. I also wanted to supplement the interviews with other material from a variety of sources and archives, including the Butetown History and Arts Centre (BHAC). Two things became apparent mid-way through the dissertation year. The first was that finding interviewees was more complicated than I had anticipated and, secondly, access to BHAC's archives was not quite as straightforward as I had assumed it would be. Shifting the focus of my dissertation to 'access' meant I could reflect on my experience of doing research in this area as well as thinking about possible ways forward for research into women's pasts in Wales.

Traditionally, record offices and their archives have generally not been places where many people, particularly marginalised groups women, ethnic minorities, working class - have found much about their history and as Carolyn Steedman suggests: what is in the record office is only 'fragmentary traces of the past' recorded and kept as history. ${ }^{14}$ How people connect with the past can be important in helping create a sense of identity by being able to deconstruct dominant histories and produce alternative histories. To help achieve this, some historically marginalised groups have created their own archives and spaces which

can be viewed as a way of retaining control over their communities' cultural property and identity; and still serves as a model for marginal groups today, be they black, Muslim or white working class communities. ${ }^{15}$

For feminist historians in Wales this has been complicated by the fact that there is no physical space to hold material relevant to women's lives which would be easily accessible. For the Archif Menywod Cymru/Women's Archive of Wales (WAW), starting out in 1997, the cost and time involved in raising funds for such a space was measured against the need to 'rescue' sources of women's history which is arguably the more pressing. ${ }^{16}$ However, BHAC began 'rescuing' their community's history nearly thirty years ago and have managed to maintain part of an old docks office building which not only contains their archive material but has a gallery space which is also used for other events. 


\section{A Brief History of Butetown}

'Tiger Bay' is probably the more familiar name to most people for the area of Butetown in Cardiff that was home to one of the oldest and largest multi-cultural communities in Britain. The origins of the community began with the construction of the Cardiff Docks by the Marquis of Bute in the mid-nineteenth century to exploit the opportunities provided by the rapid expansion of the South Wales coalfield. ${ }^{17}$ Exporting coal across the world's trade routes, seamen working on the ships arrived in Cardiff, many from the countries of Britain's empire as well as from Europe. The permanent labour force at the docks in the mid to late nineteenth century comprised mainly Welsh and Irish workers, with others from Scotland and England. ${ }^{18}$ Many seamen arriving in Cardiff stayed in boarding houses and then returned to their home countries. Others, however, settled in Butetown and married local women, many of them Welsh women from the South Wales valleys. ${ }^{19}$ These families were the first generation of the multicultural community of Butetown - a community considered unique in Britain due to the level of intermarriage between local women and immigrant seamen. ${ }^{20}$ (In the 1940s, it was estimated that there were 45-50 nationalities represented within the Butetown community in a population of approximately $5000 .^{21}$

An early glimpse of the lives of Welsh women in the community was provided by Paul Thompson's interview with Harriet Vincent which was included in his book The Edwardians, first published in $1975 .{ }^{22}$ The book was the result of a large-scale oral history project in which 'over 400 hundred men and women, all born by 1906 , and the earliest in 1872' were interviewed. ${ }^{23}$ Harriet was born to a black West Indian father and white Welsh mother and grew up in a comfortably lower middle-class family in Butetown. The population of the community was still relatively low compared to what it would be following the First World War and Cardiff was prospering at this time. Amongst other things, Harriet's narrative offers clues that Butetown's borders were not always restrictive particularly as Harriet and her first husband - a West Indian - moved to the Rhondda. However, more importantly, not only did Harriet's white Welsh mother and her two sisters marry West Indians; they also came from a family who would probably have had something of a respected position in the community due to the fact that Harriet's grandfather was a ship's pilot in the Bristol Channel. They were not women who had for one unfortunate reason or another made their way to Butetown as later commentators would suggest. But it seems they were part of the settled 
white community which had been in existence in the area since about the 1850s.

As with many other dockland areas, there was a distinct 'sailortown' character to the district but this was generally confined to Bute Street ${ }^{24}$ the main thoroughfare from the city to the docks which adjoined Butetown. The myths and legends of 'Tiger Bay' were fashioned out of the notoriety of Bute Street. ${ }^{25}$ Some historians and other commentators have rightly considered Butetown and Bute Street to be two distinct areas but in the early twentieth century the wider public in Cardiff tended to 'link the foreignness of the former to the vice of the latter. ${ }^{26}$

At the end of the First World War, demobbed White, British servicemen became hostile towards Black sailors who had seemingly taken over their jobs and 'race' riots erupted at Liverpool. Following relatively minor disturbances in nearby Newport and Barry, three black men were killed and dozens injured in Cardiff. An alleged flashpoint seems to have been the sight of black men and their white wives returning to Butetown from an outing. ${ }^{27}$ In the aftermath of the riots, Butetown began to consciously consolidate and strengthen community bonds. Marika Sherwood notes that:

The people of the Bay formed many kinds of associations to defend themselves, to struggle against injustice and inequality, to rally to the aid of colonial causes, and to provide their own social and spiritual needs. ${ }^{28}$

As a community, Butetown was marginalised not only geographically from the rest of the city but also culturally, economically and historically. Although not quite a ghetto - perhaps a 'quasi-ghetto' as Leonard Bloom suggests ${ }^{29}$ - there was a sense of 'them and us' and 'otherness' between the community and the wider city. This was also a period when Butetown's white wives and their mixed race daughters became very much more visible albeit through inaccurate and lurid newspaper reports and social investigations.

\section{Research ANd Popular CULtURE}

Much of what is 'known' about the women of Butetown came from official bodies and investigations as well as academic researchers outside of Butetown. ${ }^{30}$ Kenneth Little's PhD thesis, 'Negroes in Britain', was published in 1948. Part 1, entitled 'The Coloured People of Cardiff', was originally published separately in 1942. It is generally considered to be the most comprehensive survey of Butetown and as Neil Evans puts it, 'anyone attempting to write on Butetown must wage a struggle for 
independence from the work of Kenneth Little' ${ }^{31}$ However, his is the work of an 'old school' British anthropologist and so some of his 'findings' need to be seen in that context and treated with caution.

Along with Little, the social research organisation Mass Observation was also active in Butetown during the Second World War as part of an investigation into 'labour and morale' in the Liverpool and Cardiff docks. ${ }^{32}$ Links between Mass Observation and Picture Post and the British documentary movement were evident in the photo-essay published on 'Cardiff' in 1939 which featured 'Tiger Bay' ${ }^{33}$ Humphrey Spender was the photographer following his earlier work for Mass Observation in 1937-38. ${ }^{34}$ Picture Post returned to the area in 1950 and in $1954^{35}$ and the photographs taken by Bert Hardy are considered by residents to be a truthful representation of the community. ${ }^{36}$

During the 1940s and 1950s, newspapers and literature continued to reproduce stereotyped representations of Butetown. The Girl from Tiger Bay by Roland Vane (1950) was one of a number of British 'pulp fiction' books produced after the Second World War featuring Tiger Bay as a setting. ${ }^{37}$

The film Tiger Bay (1959), part of the British New Wave film movement is remembered fondly by older residents of Butetown particularly as much of it was shot in the area and locals were also hired as extras. It is one of the first British films to portray a multi-racial community. But it is not without problems in terms of how the women of the community are represented. ${ }^{38}$

By the time Picture Post returned to the area in 1954, the docks were in terminal decline and eventually in the early 1960s all remaining coal exports from Cardiff were abandoned. The years of negative representations of the people of Butetown had a more obvious impact on the community, particularly in relation to the 'slum' clearance policy, which emerged as an issue in the late 1930s and was eventually carried out in the 1960s. ${ }^{39}$ By 1966, most of Butetown's old Victorian housing had been demolished and replaced by tower blocks and other new housing and many residents moved to other areas of Cardiff.

\section{RESCUING BUTETOWN's HISTORY}

In 1987, the Cardiff Bay Development Corporation (CBDC) was formed to re-develop one sixth of the dockland area with the aim of reconnecting the City of Cardiff with the sea. At the same time, deciding that it was urgent that something was done to record the history of the area before it disappeared, Iain Tweedale, a post-graduate student, offered a community education course called 'The History of Butetown' 
and it was at these classes that the first recordings of some of the older residents of the community took place. Glenn Jordan, an AfricanAmerican anthropologist who had come to Cardiff to do his doctoral thesis, was also involved and he went on to form an informal group called the Butetown Community History Project with local residents. Recording of residents continued to take place through a community education course called 'The Way We Were: Life Histories from Tiger Bay' ${ }^{40}$ Jordan described this phase of BHAC's development as

A serious attempt to develop a group of locally based indigenous researchers - working-class, organic intellectuals - and to create a space for the production of alternative histories, identities and representations of life in Cardiff docklands. ${ }^{41}$

Continuing to record older residents over the next two years or so, the aim was that the transcribed material would be put onto computer where it could be easily accessed. In the summer of 1991 transcription of the recordings began but unfortunately it did not get very far. ${ }^{42}$

\section{BHAC'S ORAL HISTORY COLLECTION}

It is difficult to be specific about what exactly is in BHAC's oral history collection as they don't appear to have a catalogue which can be freely consulted. However, in 2001 a survey of BHAC's collection was carried out by the Caribbean Studies Black and Asian History (CASBAH), a web-based project funded by the Research Support Libraries Programme to 'map' resources relevant to Caribbean and Black and Asian history in the United Kingdom. The project worked in partnership with a number of organisations including the Black and Asian Studies Association (BASU), the Public Record Office and the Institute of Commonwealth Studies. ${ }^{43}$ CASBAH lists BHAC as a 'Specialist repository' and they ascertained that there are 150 audiotapes of life histories recorded between 1979 and 1989. There are also apparently 45 tapes devoted to women's lives in the community. Access to these and other collections at $\mathrm{BHAC}$ is at the discretion of the director of $\mathrm{BHAC}$, who is at present Glenn Jordan. Other collections include documents from local companies and shipping firms and approximately 5000 photographs. Jordan himself has commented that:

Our oral history archive now includes about 800 hours of audio-recorded interviews and a dozen hours of video... We have not yet been able to make substantial use of this 
material. Because of the resources required, transforming audio-recorded interviews into a form that can be shared with a public audience of readers or listeners can pose serious difficulties for groups such as ours. ${ }^{44}$

Depending on exactly what BHAC agreed with their interviewees at the time of recording, it may well be that they are not conforming to the ethical guidelines and ideas of best practice set out by the British Oral History Society. ${ }^{45}$ Firstly, it appears that many of the interviews have not been transcribed. Secondly, it seems the intention was to produce life histories of men and women from Tiger Bay so it is quite likely this is what the interviewees were told was the purpose of the interviews. An obvious solution to this might be to apply for funding which could enable a large-scale transcription project but this would probably raise the issue of wider access and availability which could mean researchers independent of BHAC producing work which perhaps doesn't tie in with BHAC's aims.

Jordan has acknowledged the irony of not allowing the voices of the 'most marginalised' to be heard, 'despite our lofty, culturally democratic aims' but ethically BHAC do need to make sure these voices are heard. ${ }^{46}$ In reflecting on the relationship between the researcher and the informant in oral history interviews, Karen Olson and Linda Shopes use the word 'entrusting' to describe the responsibility that informants give researchers to present their stories to a wider audience, particularly when they are not able to 'access' this audience themselves. ${ }^{47}$

\section{BHAC ANd Photographic Representation}

BHAC's more recent work has seen a shift to photographic representation as a way of countering traditional stereotypes which means there is less emphasis on historical research into the community:

Producing books from audiotapes is a long, laborious and costly business. From our early days we have intended to produce two volumes of life histories: Women's Lives from Tiger Bay and Men's Lives from Tiger Bay... To date this has not happened... ${ }^{48}$

This is a shame as in the mid-1990s they began to publish a number of books written by local people about the history of the area and their memories of life in the community. ${ }^{49}$ These books are valuable not only because of the people, places and events they describe but also that women feature prominently, particularly in Neil Sinclair's book, The 
Tiger Bay Story. ${ }^{50}$ However, not everyone's memories are necessarily the same, as Sinclair acknowledged in the foreword to the tenth Anniversary edition of the book:

Reading Neil's book was like being in Miss Ollie's front room trading stories. Strangers would believe it but for those who know, it was a load of rubbish. When, and if, I ever complete my True Tales of Tiger Bay, if people don't agree with it they can take it up with the folk I'll have got the stories from... ${ }^{51}$

Sadly, True Tales has yet to appear in print.

Reflecting BHAC's shift to photographic representation are two recent projects, the first of which was Somali Elders: Portraits from Wales consisting of portraits taken by Glenn Jordan and short autobiographies of his subjects which was published in 2004. It was made possible with a grant from the Home Office via the 'Connecting Communities' initiative..$^{52}$ The book is devoted entirely to the men of the Somali community in Wales - mainly Cardiff and Newport - who were born in Somaliland and settled here. The second project, funded by the Heritage Lottery Fund, was 'Mothers and Daughter' $\mathrm{s}^{\prime 53}$ which again features photographs taken by Glenn Jordan. The exhibition aims to challenge stereotyped notions that to be Welsh is to be white ${ }^{54}$ and includes women from all over Wales with diverse multi-ethnic backgrounds.

Accompanying the portraits are brief oral histories which were conducted at the time the photographs were taken and which will be published as part of an educational package for teachers. ${ }^{55}$ The project has its roots in a group of young Somali women approaching Jordan to take photographs of their mothers following the Somali Elders project, mentioned above. The initial exhibition was shown in Ireland and was funded by the Arts Council of Wales who awarded an Individual Artist Grant to Jordan. ${ }^{56}$ These projects reiterate notions of 'otherness' and the accompanying text is framed around discussions of identity and difference. Both of these projects illustrate the shift in BHAC's approach, from what was initially a community history project to a more contemporary arts and cultural organisation. Jordan doesn't see this as abandoning their 'commitment to cultural democracy'; it allows a broader range of publications, such as those that 'privilege visual imagery, particularly photographs ${ }^{\prime}{ }^{57}$ 


\section{THE BAY PEOPLE'S MUSEUm}

The more recent emphasis on photographs does seem to tie in with BHAC's long-standing aim to create a 'Bay People's Museum' in Cardiff Bay 'which would include the Bay People's Archives, together with exhibition halls, a café, a pub, activities for children and so on' ${ }^{58}$ BHAC had hoped that the CBDC would, as part of their $£ 1.66$ billion regeneration fund, establish a museum and arts centre which would be run by BHAC and provide 'an essential heritage attraction in a redevelopment which had paid little attention to the multi-cultural history of the area'. ${ }^{59}$

Unfortunately, this didn't happen. However, in 2008, plans to renovate the historic Pierhead building in Cardiff Bay were announced by the Welsh Assembly:

We will be working in partnership with the Butetown History \& Arts Centre and the Merchant Navy Association and have invited the National Museum and Galleries to be a partner in the interpretation of the building... I see there being four stories around the Pierhead. The first is looking out to sea to tell the seafarer's history while towards the west is Butetown and it is important to tell the history of black culture and its links with Cardiff. To the east there is the new democracy shown by the Senedd and towards the back we look up to Castell Coch and the rest of Wales. ${ }^{60}$

On a recent visit to the Pierhead, it was disappointing to see virtually no mention of the Butetown community, except for an A4 sheet of recollections by Neil Sinclair, and there didn't seem to be any evidence of a partnership with BHAC. In light of Butetown's historic, cultural and social marginalisation within wider Cardiff and South Wales, it is possible that an agreement couldn't be reached over how the history of the area was to be interpreted. There is also the issue of what might be seen as 'cultural appropriation' ${ }^{61}$ in that much of the material collected by BHAC has been donated by families and so issues arise around how to display material to be viewed in a 'heritage' setting. As Darryl McIntyre notes: 'It is never easy for a publicly funded cultural institution to become involved in controversy but that is probably inevitable if the museum is to do its job honestly. ${ }^{62}$ In this instance, it seems that the Welsh Assembly have chosen to avoid the issue entirely. 


\section{ARCHIF MenYwod CymRu/Women's ARCHIVe Of WaLeS}

the bottom line is 'does it throw light on the history of women in Wales, including very recent history' ${ }^{63}$

The Women's Archive of Wales (WAW) was founded in 1997 and was the 'brainchild' of Ursula Masson, a lecturer in history at the University of Glamorgan, who acted as Chair until her death in 2008. Along with Deirdre Beddoe, Emeritus Professor of Women's History, who is the President of WAW, she was active in promoting women's history to a wider community in Wales:

[WAW] exists to promote the study, and to rescue and preserve the sources, of women's history in Wales... We collect a broad range of archival, photographic and other material sources which illustrate the history and heritage of women in Wales, and their experience in a range of spheres including the domestic, political, religious, economic, cultural and social. We particularly seek diaries, scrapbooks, the minute books of women's organizations, literary manuscripts, photographs and similar materials. Our collections are deposited in our name in existing record offices in Wales, and in the National Library of Wales, where they are properly cared for, and where they can be accessed by researchers subject to any restrictions put on a collection. ${ }^{64}$

So although WAW, unlike BHAC, does not 'physically' hold its own collections, it might be described as a 'portal or gateway' for researchers. ${ }^{65}$ It has a formal agreement with the record offices and National Library of Wales and they work within the collection policies of those institutions. For local record offices it is documentary material and photographs relative to their specific geographical area and the National Library of Wales takes the broader Welsh collections. WAW's collections are listed on the Archives Network Wales website, a publicly funded project allowing searchers to see what material is held across Wales. ${ }^{66}$

An obvious solution for housing a women's collection might have been a Women's Library or similar space. Alyson Tyler conducted research for her PhD thesis into other women's libraries/spaces in Britain, to see whether there was a need for such a space in Wales ${ }^{67}$ and interviewed four members of WAW.$^{68}$ Aside from the difficulties of funding and maintaining a 'Women's space/archive', another important 
issue in a Welsh context would have been where to site such a space, particularly as there has been a perceived (biased?) distinction between the English-speaking South and the Welsh-speaking North. It is probably fair to say that the drive to promote women's history in Wales has largely been led by feminist historians from the South and this issue was identified in WAW's Acquisitions report of 2005-06 in that most of their collections came primarily from South Wales ${ }^{69}$ although this has now begun to change. ${ }^{70}$ Placing material donated to them into existing record offices also enables WAW to 'promote' and engage county archivists across Wales with the importance of women's history. Being able to utilise new digital technologies which are becoming more widely available was also seen as the way forward. ${ }^{71}$

Because women and other marginalised groups have found little of their own pasts in traditional archives such as local record offices it could be argued that groups such as WAW are attempting to redress this, although this will obviously not happen overnight. In terms of WAW'S collections, it seems likely that more recent material around events like the Miners' Strike in 1984-85 is from and about working class women but the bulk of earlier material is likely to be from middle-class women. ${ }^{72}$ Another important issue is the lack of material from women in ethnic communities across Wales.

\section{WAW'S WOMEN'S HISTORY ROADSHOWS}

A recent project which has brought WAW to a wider public has been the Women's History Roadshows project. These, too, were the idea of Ursula Masson and the project was launched in January 2008 at the Senedd in Cardiff and the final roadshow took place in Merthyr Tydfil in June 2009. The project was funded by a HLF Heritage Grant of $£ 187,000 .^{73}$

The aim of the project was to encourage people to bring in material relating to women's lives, to offer them a historical 'valuation'. Specialists in archives and libraries gave advice on conservation of material for people who didn't wish to donate it but permission was sought to scan items for the WAW website and record interviews. Historians, including Angela John and Catrin Stevens, were on hand to suggest how the material might 'throw light on the history of women in Wales' ${ }^{74}$ Where donations were made, the material was deposited in the relevant record office under WAW's name.

Perhaps unsurprisingly, much of the material appearing at the roadshows was in the form of photographs. However, although WAW's 'call' had been for letters diaries and photographs relating to women's lives, interestingly and perhaps not anticipated, was the amount of non- 
documentary material people brought to the roadshows. This demonstrates the many and varied ways people make their own connections with the past and the personal value and 'meaning' they attach to different items. ${ }^{75}$ At a roadshow event I attended in Monmouth in 2008, the concert dresses and photographs of Marie Novello were brought in and donated. Originally from Maesteg in Bridgend, Marie was the adopted daughter of Dame Clara Novello and sister of Ivor Novello but she died at the age of 30 in 1928 and since then had been largely forgotten. The dresses were extremely fragile and bits of beading were falling off them as they were unwrapped. For WAW, one of the issues is that local record office collection policies don't extend to this sort of material which is where museums needed to be involved and a museums advisor has since been sought for the committee. Another unexpected bonus from the roadshows was the number of people who were keen to share their memories and stories about the material they had brought in but didn't want to donate. These interviews have formed an oral history archive which will be made accessible via the archive's website.

Another aspect of the roadshows is that at each roadshow there are often other groups present who provide exhibitions, assistance and speakers for the events. One particular group is Merched y Wawr (Women of the Dawn) which is a group that broke away from the Women's Institute (WI) in the late 1960s after the WI insisted that all meetings had to be conducted in English. The group is active in mid and North Wales and working with groups such as these helps to extend links beyond South Wales and into Welsh-speaking areas. ${ }^{76}$

A further result of the roadshows has been that the archive has made grassroots connections at a level that local record offices can't necessarily make. In the course of doing research for my MA dissertation, I came across a company in Cardiff called J R Freeman, a cigar factory which had been a longstanding employer of women in the docks area. When I contacted the company, I was invited in to have a look at the company's archive which contained photographs of women who had worked there in the 1920s and 1930s, the period I was particularly interested in. Aside from these photographs, the collection includes a substantial number of photographs of women working there from nearly every decade of Freeman's 100-year history in Cardiff. The company was due to close for good in September 2009 and there was a possibility that the collection could end up with the parent company in Japan. To this end, I passed on the relevant details to the Women's Archive and the Glamorgan Record Office has been able to reach 
agreement with the company for the collection to be deposited in the Record Office under the Women's Archive name, which will enable the material to be accessed by all kinds of researchers. I'm not sure that if I hadn't heard or known about the Women's Archive whether I would have thought to mention the Glamorgan Record Office instead.

\section{CONCLUSION}

As can be seen, the core ethos of both BHAC and WAW has been to 'rescue' and preserve material which can be used to produce alternative histories of marginalised groups in Wales. BHAC has moved on from this to some degree and now seems to concentrate on representing the wider community of multi-ethnic Wales in a variety of ways, particularly photography, and much of this is new, contemporary work. This has tended to relegate producing histories of the Butetown community, from their existing material, to the sidelines. Although BHAC is interested in the historical representations of the residents of Butetown, it is more concerned with the ways in which people from the community can represent themselves now. This does mean that the voices of earlier generations, in this case, the women of the community, are rarely heard and so the stereotyping and negative representations of these women remain unchallenged. However, it has managed to retain control and access to its own material and to set its own agenda and aims.

WAW's approach has been to make any material they can 'rescue' accessible in local record offices to all researchers as well as making much of it available digitally where possible. Not having a women's library or similar space in Wales might, perversely, be viewed as an advantage. It could be perceived as being too specialist, and there can be difficulties in competing for funding with other British women's libraries/spaces. There are issues as to how well certain groups of women are represented in WAW's collections but their work does help to raise awareness that more material and more research is needed to expand our knowledge of women's pasts in Wales.

The image of the Welsh 'mam' has been exposed as a nineteenthcentury invention and largely a figment of popular cultural imagination. Some of the 'gaps' left since the 'mam' has been consigned to the old, outdated histories of Wales are starting to be filled with new, alternative histories of Welsh women and access to new and existing material is essential for this to continue. 


\section{ENDNOTES}

${ }^{1}$ Angela V John, (ed), Our Mothers' Land: Chapters in Welsh Women's History 1830-1939, University of Wales Press, Cardiff, 1991, Introduction, p1.

${ }^{2}$ Deirdre Beddoe, 'Images of Welsh Women' in Tony Curtis, (ed), WALES: The Imagined Nation. Essays in Cultural and National Identity, Poetry Wales Press, Bridgend, 1986, p227.

${ }^{3}$ John, Our Mothers' Land, p1.

${ }^{4}$ Rosemary Crook, 'Tidy Women': Women in the Rhondda between the wars', Oral History: The Journal of the Oral History Society, vol 10, no 2, Autumn 1982, pp40-41; Beddoe, 'Images of Welsh Women', p229; Carol White and Sian Rhiannon Williams (eds), Struggle or Starve: Women's lives in the South Wales valleys between the two World Wars, Honno Press Dinas Powys, 1998, p12 \& p15.

${ }^{5}$ Deirdre Beddoe, Out of The Shadows: A History of Welsh Women in Twentieth-Century Wales, University of Wales Press, Cardiff, 2000, p78.

${ }^{6}$ For example, Maggie Jones from the Rhondda, interviewed in the documentary Mam recalled her mother taking in washing and being paid two shillings. Interviewed in Mam, Red Flannel Films, Pontypridd, Mid Glamorgan, 1988; Viewing copy supplied by National Screen and Sound Archive of Wales, February 2009, Ref: 302

${ }^{7}$ Ruth Shade, "Valley Girls: reconfiguring the dramatic representation of Welsh "mams" and "slags", 2001, http://www.theatre-wales.co.uk/critical/critical detail.asp?criticalID=3 accessed $22^{\text {nd }}$ September $2008, \mathrm{p} 1$.

${ }^{8}$ Alison Benjamin, 'Mixed Metaphor' The Guardian, 14 March 2001, http://www.guardian.co.uk/society/2001/mar/14/guardiansocietysupplement5 accessed 19 February 2008.

${ }^{9}$ New research around women and work in Victorian Cardiff might begin to shed more light. See, for example, Phillip Davies, Migration and Women's Work in Late Victorian Cardiff, unpublished MA by Research, University of Glamorgan, 2008 http://history.research.glam.ac.uk/news/en/2008/jul/09/migration-and-womens-work-late-victoriancardiff/ accessed 11 September 2008. Also Harry 'Shipmate' Cooke, How I Saw It: A Stroll Thro' Old Cardiff Bay, Butetown History and Arts Centre, Cardiff, 1995, p83, describing the 'old Bay', writes that 'Bay girls no longer work in the brush factory, the sack and bag works or Zigmonds...'.

${ }^{10}$ Deirdre Beddoe has suggested that Welsh women were subject "to a particularly "virulent strain" of patriarchy', the effects of which lingered longer in Wales. Beddoe, Out of the Shadows, p180.

${ }^{11}$ See Angela V. John (ed), Our Mothers' Land: Chapters in Welsh Women's History 1830-1939, University of Wales Press, Cardiff, 1991. This was the first academic book devoted entirely to research into Welsh women's pasts. It covered the period 1839-1939 and demonstrates the variety of material historians use to construct alternative histories.

${ }^{12}$ Deirdre Beddoe has identified areas of potential research that have been neglected. The first is the overall period of 1945-1970. This is a significant time for working class women in Wales particularly in relation to employment outside the home, as this was the period when male-dominated heavy industry of all types in Wales came under threat. New, light industrial businesses began operating in Wales in the early post-war period and offered considerable employment opportunities for women when many of their husbands were losing their jobs. Other areas of potential are around women and the trade union movement and women in local government. Beddoe, Out of the Shadows, pp6; 135. Avril Rolph's opinion is that 'far more research is needed into the role women played in virtually all aspects of life in Wales through the ages...'. Email interview, Avril Rolph. 30 April 2009.

${ }^{13}$ Hilda Kean, London Stories: Personal lives, public histories, Rivers Oram Publishing Limited, London, 2004, p7.

${ }^{14}$ Carolyn Steedman, Dust, Manchester University Press, Manchester, 2001, p69.

${ }^{15}$ Jon Newman, 'Harry Jacobs: The Studio Photographer and the Visual Archive', in Paul Ashton and Hilda Kean (eds), People and their Pasts: Public History Today, Palgrave MacMillan, London, 2009, p269.

${ }^{16}$ This interview extract published in WAW, 'Newsletter', January 2009, p5, illustrates this: 'My mother was known as the gypsy in our mining community. When anyone was ill or had an accident down the mine they would turn up on our doorstep. She would go out into the wild and collect baskets of plants for her remedies. They always said I was the next in line to carry this knowledge and practice forward I was young, saw it as old fashioned and refused to take an interest. When mother died I was left note books full of her plant remedies passed down through the family. Last year I moved to a smaller flat and had no room for these books, none of my daughters were interested, nor was the local library so they ended up on the bonfire!' Mrs Johns, 89 years, Rhondda Valley.

${ }^{17}$ Dennis Morgan, The Cardiff Story, Hackman Print, Tonypandy, 1991/2001, p135. 
${ }^{18}$ Glenn Jordan, 'Down the Bay': Picture Post, Humanist Photography and Images of 1950s Cardiff, Butetown History and Arts Centre, Cardiff, 2001, p9.

${ }^{19}$ Brian Lee and Butetown History and Arts Centre, Butetown and Cardiff Docks (Images of Wales Series), Tempus Publishing, Stroud, 1999, p8.

${ }^{20}$ Alison Benjamin, 'Mixed Metaphor', The Guardian, 14 March 2001, http://www.guardian.co.uk/society/2001/mar/14/guardiansocietysupplement5 accessed 19 February 2008.

${ }_{21}^{21}$ Jordan, 'Down the Bay', p9.

${ }^{22}$ Paul Thompson, The Edwardians: The Remaking of British Society, Routledge, Abingdon, Oxford, 1992, pp94-102.

${ }^{23}$ The interviews are now part of the British Library National Sound Archive and Thompson mentions that 'this unique, now unrepeatable set of interviews has proved an extraordinary rich source for many other historians besides myself'; Thompson, The Edwardians, ppxix; xx.

${ }^{24}$ Stan Hugill, Sailortown, Routledge and Kegan Paul, London, 1967, p128, recalls seamen also referring to Bute Street as 'Oriental Parade'.

${ }^{25}$ Neil Evans, 'Regulating the Reserve Army: Arabs, Blacks and the Local State in Cardiff, 1919-1945' in Kenneth Lunn (ed), Race and Labour in Twentieth-Century Britain, Frank Cass \& Company Ltd, London, 1985, p70; Ross Cameron, “"The Most Colourful Extravaganza in the World": Images of Tiger Bay, 1845-1970', Patterns of Prejudice, vol 31, no 2, 1997, pp59-90; 68.

${ }^{26}$ Cameron, 'The Most Colourful Extravaganza in the World', p68. This article examines the emergence of the myths surrounding 'Tiger Bay'.

${ }^{27}$ See Laura Tabili, 'Women "of a Very Low Type”: Crossing Racial Boundaries in Imperial Britain', in Laura Frader and Sonya O. Rose (eds), Gender and Class in Modern Europe, Cornell University Press, Ithaca, 1996, p166: 'Early twentieth-century observers frequently attributed racial conflict to sexual competition - competition among Black and white men for white women.' For an in-depth account of the riots in Britain and the sequence of events in Cardiff see Peter Fryer, Staying Power: The History of Black People in Britain, Pluto Press, London, 1984, pp304-9 and Neil Evans, 'The South Wales Race Riots of 1919', Llafur, vol 3, no 1, 1980, pp5-29.

${ }^{28}$ Marika Sherwood, 'Racism and Resistance: Cardiff in the 1930s and 1940s', Llafur, vol 5, no 4, 1991, pp51-70; 58.

${ }^{29}$ Leonard Bloom's Introduction to Kenneth Little, Negroes in Britain, Routledge and Kegan Paul Ltd, London, 1972, p44.

${ }^{30}$ For example, Captain F. A. Richardson's report to the British Social Hygiene Council and the British Council for the Welfare of the Mercantile Marine: 'Cardiff has before it a social problem that cannot as yet be solved... The coloured men who have come to dwell in our cities are being made to adopt a standard of civilisation they cannot be expected to understand... They come into intimate contact with white women, principally those who unfortunately are of loose moral character, with the result that a half-caste population is brought into the world.' Quoted in the Western Mail, 8 July 1935. From Alan Llwyd, CYMRU DDU: Hames Pobl Dduon Cymru/BLACK WALES: A History of Welsh Black People, Hughes, Llanishen in association with Butetown History and Arts Centre, 2005, p112.

${ }^{31}$ Evans, 'Regulating the Reserve Army', p109.

${ }^{32}$ Tony Kushner, We Europeans?: Mass-Observation, 'Race' and British Identity in the Twentieth Century, Studies in European Cultural Transmission series, Ashgate Publishing, Aldershot, Hampshire, 2004, p79.

${ }^{33}$ Picture Post, 'Cardiff', 18 March 1939, Hulton Press, London, pp21-29.

${ }^{34}$ Kushner, We Europeans?, p80.

${ }^{35}$ Picture Post, 'Down the Bay', 22 April 1950, Hulton Press, London, pp12-19 and Picture Post, 'The best, and the worst of, British cities: 2: Cardiff', 23 January 1954, Hulton Press, London, pp32-37.

36 'Well that's how it was. He has captured how we lived. It's down to earth, it's real.' Clara Graham quoted from Glenn Jordan, 'Down the Bay': Picture Post, Humanist Photography and Images of 1950s Cardiff, Butetown History and Arts Centre, Cardiff, 2001, p12.

37 'Why are certain types of white women attracted - apparently irresistibly - towards coloured men? The question has intrigued scientists, psychiatrists and social workers for centuries. Now Roland Vane in this frankly realistic novel delves into the reasonings of a woman of this type.

Born in a Cardiff slum and reared in the sordid sophistication of 'Tiger Bay', his heroine finds herself drifting, through no fault of her own, into the arms of the only individual who has ever shown her kindness - a coloured man!' Back-cover to Roland Vane, The Girl from Tiger Bay, Archer Press Ltd, London, 1950. Quoted from Babylon Wales website http://babylonwales.blogspot.com/2006/07/girlfrom-tiger-bay.html accessed 20 February 2008.

${ }_{38}$ Tiger Bay, Independent Artists (Productions) Ltd, 1959. (Reissued on DVD by Carlton, 2004.) The portrayal of the women in the film reflects Ruth Shade's 'mams' and 'slags' although there is also a 
racial element. The 'mams' in the film (all Welsh) are invariably seen wearing aprons, in the home working at some domestic task. They look tired and put-upon, and in Mrs Parry's case (Rachel Roberts), seemingly quite old to have such a young child. No make-up, hair short or pinned back neatly. No obvious adornment or make-up and their clothes are dowdy. The 'other' women, Anna, the murdered Polish woman and Christine, the mixed-race, 'tart with a heart' are a complete contrast: Make-up, jewellery, styled hair, often scantily-clad, exotic and 'glamorous' in a sense, these portrayals tap into stereotypes of women from Butetown.

${ }^{39}$ Glenn Jordan and Chris Weedon, 'When the Subalterns Speak, What Do They Say? Radical Cultural Politics in Cardiff Docklands' in Paul Gilroy, Lawrence Grossberg and Angela McRobbie (eds), Without Guarantees: In Honour of Stuart Hall, Verso, London, 2000, p171.

${ }^{40}$ Glenn Jordan and Chris Weedon, 'Whose History Is It?', in Cultural Politics: Class, Gender, Race and the Postmodern World, Blackwell, Oxford, 1995, p141.

${ }^{41}$ Glenn Jordan, 'Voices from below: doing people's history in Cardiff Docklands', in Stefan Berger, Heiko Feldner and Kevin Passmore (eds), Writing History: Theory and Practice, Hodder Arnold, London, 2003, p304.

${ }^{42}$ Jordan and Weedon, 'Whose History Is It?', p142.

${ }^{43}$ CASBAH, nd, p2 http://www.casbah.ac.uk/index.html accessed 25 May 2008.

${ }^{44}$ Jordan, 'Voices from below', p309.

${ }^{45}$ Oral History Society, 'Oral History Society Ethical Guidelines', nd, http://www.ohs.org.uk/ethics/index.php - eg accessed 13 June 2009.

46 Jordan, 'Voices from below', p309.

${ }^{47}$ Karen Olson and Linda Shopes, 'Crossing Boundaries, Building Bridges', in Sherna Berger Gluck and Daphne Patai, (eds), Women's Words: The Feminist Practice of Oral History, Routledge, London and New York, 1991, p198.

48 Jordan, 'Voices from below', p309.

${ }^{49}$ See Neil Sinclair, The Tiger Bay Story, Butetown History and Arts Centre, Cardiff, 1993; Phyllis Grogan Chappell, A Tiger Bay Childhood, Butetown History and Arts Centre, Cardiff, 1994; Harry 'Shipmate' Cooke, How I Saw It: A Stroll Thro' Old Cardiff Bay, Butetown History and Arts Centre, Cardiff, 1995.

${ }^{50}$ Neil Sinclair, The Tiger Bay Story: $10^{\text {th }}$ Anniversary Edition, Dragon and Tiger Enterprises, Cardiff, $1993 / 2003$

${ }^{51}$ Quoted from Sinclair, The Tiger Bay Story, pvii. This was a letter from Peggy Farrugia, a local resident, writing to Making Waves magazine in October 1993.

${ }^{52}$ Glenn Jordan, Somali Elders: Portraits from Wales, Butetown History and Arts Centre, Cardiff, 2004, p4.

${ }^{53}$ South Wales Echo, 21 August 2008, 'Mothers and daughters exhibition', http://www.walesonline.co.uk/showbiz-and-lifestyle/features/2008/08/21/mums-and-daughters-bringwales-rich-tapestry-to-life-91466-21575067/ accessed 5 January 2009.

54 Glenn Jordan, 'Mothers and Daughters: Portraits from Multi-ethnic Wales. A photographic exhibition by Glenn Jordan'. Forum on Migration and Communications, Ireland, 2007, p10. (Pamphlet produced for Irish exhibition.)

${ }^{55}$ Education is an important part of BHAC's work and material from their collections has been used in resource packs for teachers and sent out to schools. Alison Benjamin, 'Mixed Metaphor', The Guardian, 14 March 2001, http://www.guardian.co.uk/society/2001/mar/14/guardiansocietysupplement5, accessed 19 February 2008

${ }^{56}$ Glenn Jordan, 'Mothers and Daughters', p13.

${ }^{57}$ Jordan, 'Voices from below', p311.

${ }^{58}$ Jordan and Weedon, Whose History Is It?, p150.

${ }^{59}$ Alison Benjamin, The Guardian, 14 March 2001, 'Mixed Metaphor', http://www.guardian.co.uk/society/2001/mar/14/guardiansocietysupplement5, accessed 1 February 2008.

${ }^{60}$ South Wales Echo, 29 February 2008, 'Museum planned for historic bay building', http://www.walesonline.co.uk/news/wales-news/2008/02/29/museum-planned-for-historic-baybuilding-91466-20541205/ accessed 1 March 2009.

${ }^{61}$ Newman, 'Harry Jacobs', p261.

${ }^{62}$ Darryl McIntyre, 'Creating New Pasts in Museums: Planning the Museum of London's Modern London Galleries', in Ashton and Kean, People and their Pasts, p139.

${ }^{63}$ Email interview with Avril Rolph, Archif Menywod Cymru/Women's Archive of Wales Committee Member, Thursday 30 April 2009. 
${ }^{64}$ Archif Menywod Cymru/Women's Archive of Wales website, nd, http://www.womensarchivewales.org/en/index.html accessed 27 Feb 2009.

${ }_{65}$ Alyson Tyler, Chapter 1 of thesis, 2006, http://cadair.aber.ac.uk/dspace/bitstream/2160/254/21/Chapter 1.pdf accessed 1 March 2009

${ }^{66}$ Archive Network Wales, nd, http://www.archivesnetworkwales.info/ accessed 11 April 2009.

${ }^{67}$ Alyson Tyler, Chapter 1 of thesis, 2006, http://cadair.aber.ac.uk/dspace/bitstream/2160/254/21/Chapter 1.pdf accessed 1 March 2009.

${ }^{68}$ Email interview, Avril Rolph, 30 April 2009.

${ }^{69}$ WAW, Annual Report, 2005-2006, p14.

http://www.womensarchivewales.org/en/membership/index.html accessed 8 April 2009.

70 "At the Conference last year, members from north Wales formed a regional group and have met together on a number of occasions, including organising a conference "Sharing our Histories" for International Women's Day when over a hundred women from across North Wales attended.' Archif Menywod Cymru/Women's Archive of Wales, Annual Report, 2007-8, p1.

${ }^{71}$ Email interview, Avril Rolph, 30 April 2009.

${ }^{72}$ Email interview, Avril Rolph, 30 April 2009.

${ }^{73}$ Heritage Lottery Fund 'WAW', nd, http://search.hlf.org.uk/English/GrantsDatabase/grantsproject?applicationID=21754 accessed 28 April 2011

74 'Women's lives revealed... virtual archives to roadshows', CyMAL Magazine, issue 3, Winter 2006, p19,

http://cymru.gov.uk/docrepos/40382/DeptLGandC/403822131/4038221336/648954/CyMAL issue3 E Final.pdf?lang=en accessed 2 June 2009.

${ }^{75}$ Kean, London Stories, pp6-9.

${ }^{76}$ Merched y Wawr carried out a HLF funded 'Oral History of Women in Wales (1920-1960)', in which volunteers interviewed 1000 Welsh-speaking women across Wales about issues relevant to women's lives. The tapes have been deposited at the Museum of Welsh Life in St Fagan's, Cardiff, Catrin Stevens, who also works with WAW, co-ordinated the project - Heritage Lottery Fund 'Merched y Wawr', nd, http://www.hlf.org.uk/ourproject/Pages/Feb2000/cd09434d-b6ae-4071-b591cb59f6f2262d.aspx accessed 28 April 2011. 